\title{
Project Approach in Environmental Education
}

\author{
Heny Djoehaeni, Ocih Setiasih, Leli Kurniawati, Asep Deni Gustiana
}

Universitas Pendidikan Indonesia

Corresponding e-mail: henydjoe@upi.edu, henydjoe@yahoo.com

\begin{abstract}
Humans and environment are an integral part. Environmental problems that occur recently will affect the quality of human life. Environmental education is a solution to form an aware human in maintaining and preserving the surrounding environment. Some experts believe that environmental education that introduced early can be a basis establishment of good character in children. The experience of learning that takes place at an early age will become the foundation for subsequent learning experiences. Many fundamental qualities of importance to environmental education can develop significantly during early childhood. The learning experiences in early childhood are ideally delivered through direct experiences that are meaningful and fun. Project Approach is one approach that appropriate to facilitating children's learning in environmental education. Project approach can help children develop cognitive skills, especially problem-solving skills, as it exposes them to the everyday problems such as environmental problems, which demand solutions. Through the project approach a child has the opportunity to work in group to develop social skills and especially skills in collaborating with others. This discussion will be focused on conceptualization of environmental education and project approach as one of the strategy that can be used in early childhood setting.
\end{abstract}

Keywords: environmental education, early childhood, project approach

\section{INTRODUCTION}

Environmental problems that occurred lately mostly come from human negligence. Poor management of the environment that arises is a result of a lack of awareness of some people in maintaining the environment, indifference, and lack of understanding about environmental conservation provide very significant impacts on human life.

Looking at the environmental damaged that plagues much of the world, environmental education which is inculcated early may play a significant role to develop the positive attitudes and practices around conservation and sustainability of the environment that persist in to adulthood.

Lang (2007) stated that sustainability is a big idea that tries to rethink the ways we learn, live and work together while respecting the capacity of the Earth's natural systems to support life. Similarly Press (1998:1) argued that "To 'sustain' means to support. Therefore, if our species is about to sustain, sustainability requires reducing our impact on the environment and conserving resources for future Generations.

The World Commission on Environment and Development (1987) published Our Common Future, Also known as the Brundtland Report. This international seminar work and developed the concept of sustainable development to reflect that the well-being of humanity required the rethinking of the way we worked and plan to ensure that build fairer societies coexist with one another and the environment. Education for sustainability acknowledges the critical role education plays as individuals and communities work toward sustainability. Fundamentally, education or sustainability focuses on the process of learning and change to achieve that goals and meet the challenges of sustainability. The principles of sustainability form the underlying principles for education. Environmental education as part of its educational for sustainability becomes a very important part in addressing environmental problems that arise today. 
Regarding to the role of teacher, Lang (2007) revealed that the teacher should prepare the student for learning in the environment and digging deeper. Further, Lang (2007) argued that learning in the environment requires the student to develop skills in noticing, interpreting, problem solving and theory building, as well as reporting and taking informed action generated from the learning.

Education as a conscious effort is made to change one's behavior plays a very important role in various joints of human life. Early childhood education is the foundation for the development of an individual character in his life in the future. Early childhood are often also called a fundamental phase that will determine their lives in the future. Many experts stated that education at an early age is a stage that is very fundamental to the development and further education. Victorian Environmental Education Council (1992:3) stated that the experiences of learning that take place at an early age will become the foundation for subsequent learning experiences. Thus life skills form the basis of individuals' development and to succeed in school learning in the wider community. Many fundamental qualities of importance to environmental education (such as creativity, cooperation, caring for the environment, valuing of the re-usable material and understanding the interdependence of life on earth) can develop significantly during early childhood. It is important for parents, caregivers and early childhood educators to recognize the potential of early childhood years and employ strategies to help children develop these qualities.

Environmental education instilled early expected to develop positive attitudes and environmental sustainability. Likewise that the introduction of the surrounding nature through environmental education to children from an early age for children is the first step in respecting the environment (Sutrisno, et al, 2005). Kindergarten is a place where children spend most of their time at a very important time in their lives, so that kindergarten is considered as a place that fosters knowledge of a child's environment (Meiboudhi, et al, 2011)

Some studies reveal the importance of environmental education, as stated Chen and Cheng in his study (2008) that the Environmental Education is a very important tool in providing knowledge, positive attitudes towards the environment and to build skills to protect and improve the environment.

Project Approach is one approach that appropriate to facilitating children's learning.
Project approach can help children develop cognitive skills, especially problem-solving skills. Through the project approach a child-has the opportunity to explore their environment, find new things as well as work in a group and collaborating with others.

\section{LITERATURE REVIEW}

\subsection{Environmental Education}

Stapp (1979. P.1) mentioned that environmental education is a process aimed at developing a world population that is aware of and concern about the total environment and its associated problems, and which has the knowledge, attitudes, motivation, commitments and skills to work individually and collectively toward solution of current problems and the prevention of new ones. Similar with that, Eco Schools Program. (1998:6) stated that essentially, environmental education program in schools aim to bring about changes in student attitudes and values as human interact with all components of the environment. When schools establish sound practical environmental programs, students will be able to participate actively in improving the quality of the school environment. In the majority of cases this is best undertaken with the support and cooperation of the community, including government departments and non-government agencies.

When students see they are making a realistic contribution to the environment, their learning is more purposeful, their motivation is enhanced and their self-esteem is raised. Related to the reason why should schools develop initiatives in environmental education, Eco Schools Program. (1998:7) mentioned that by participating in environmental education program, school will be able to:

1. Become more aware of their natural, social, cultural built and spatial environments

2. Enhance their students' skills in diagnosing and solving problems

3. Identify and examine significant environmental issues which will facilitate the development of student's learning and skills.

4. Demonstrate how they can put into practice the environmental education curriculum statement K-12

5. Improve the quality of the school environment

6. Demonstrate the need to care for environment

7. Utilize the natural and built environmental to facilitate student learning 
8. Enhance the relationship between students, the community and the environment.

9. Promote cooperative endeavors among students, their communities and district and national groups, leading to the improvement of degraded environments.

10. Develop in their sensitivity, and understanding of their local environment

11. Provide their students balanced perspective through integrated programs across key learning areas

12. Use a variety of teaching and learning experiences with an emphasis on practical studies.

Some points above, May considered as a practical guideline for teacher in order to design some program in environmental education in early years. The emphasis of the program should be relevant to the needs and interests of children. Kinsella (2008: p.3) stated that in today's societies we are becoming increasingly concerned about global warming, climate change and the wellbeing of the planet and in habitants for future generation. As parent and caregivers, we often worry about the future of our children, and many of us feel we could be doing more in our daily lives to contribute to the solution rather than the cause of the environmental concern of our time

In other part Kinsella (2008: p.4) also mentioned that our home and communities are where we raise our children, so it makes sense to those want to keep our home safe and healthy for them to grow and learn. We know that young children learn from relationship with their families, caregivers and the environment, so, through what we do in our daily lives, we can start involving children in learning about taking care of the world around them.

Based on Kinsella's view, there are six areas of sustainability such as energy saving, water conservation, waste minimize-rethink, reduce, reuse, recycle, gardening and composting, sustainable food practices and green play experience. In support of six areas, teacher can create some attractive learning activities.

\subsection{Environmental Education for Children}

In the early 1980s when early childhood education began to emerge and applied in the several form of child institutions, the concepts associated with understanding the physical environment that exists in are often mentioned. One of them as proposed by
Spodek (1978:126) who stated that one of the basic purposes of school is the transmission of significant portions of this knowledge to the young. This allows each generation to grasp what we know at present about the world, so that they can deal effectively with it, building upon what is already known and, in time, accumulating greater knowledge about it.

Similar with Spodek, Hildebrand (1981:194) stated that understanding the physical world is lifelong pursuit that begins in early childhood. In other part she stated that each time the child is responding to the physical world. Each responds contain some learning experience and motivation that will serve the teacher as the incidents are used to help children understand what is taking place in their world.

Spodek (1978:126) also mentioned that science, mathematics, and the social sciences have been viewed as the result of intellectual processes by which the physical and social world can be explored. Science is not the only method we have for exploring the world, but it is an important one. Sciences deal with the physical properties of the world. It orders these properties, identifies relationship among them, and establishes theories that can be empirically tested to explain the relationships identified.

In other part, Spodek (1978:127) also mentioned about a close relationship between science and environment. He stated that science was one of the later subjects to be included in the curriculum of early childhood education. In many of the pioneering approaches we do find nature studythe observation of natural phenomena primarily for the sake of appreciation rather than comprehension. Teachers were admonishing to keep a section of their outdoor play space reserved for a garden to be cultivated by the children. Small animals were kept as classroom pets, and the children learn for them. Interesting natural objects such as rocks and leaves were brought into the classroom and arranged on a table for the children to observe. Nature stories were read and pictures exhibited to further children's learning. All this activity had as its prime purpose the development of children's reverence for the outdoors and appreciation of the wonders of nature to be found around them.

In term of investigating environment The United States Department of Agriculture. (1978: p.i) stated that the participant can investigate it by collecting, recording, and interpreting information about different part of the environment, applying these interpretation by analyzing physical, social and 
economic impact on the environment in a variety of situation.

Related to that kind of activities, the lesson plan has seven components which is:

1. Suggestions for setting the stage

2. Individual or group activities

3. Flash card for some activities

4. Chart and tables to be used in data interpretation

5. Suggested question and discussion points

6. A statement of anticipated behavioral outcomes

7. List of equipment needs.

Good planning is highly dependent on the creativity of teachers in designing learning activities. The clear and rich learning stages are needed in order to create interesting learning experiences.

\subsection{Project Approach}

Various approaches and strategies can be selected by the teacher in facilitating children's learning. In the area of environmental studies, on key approach that facilitates children learning with various experiences, is Project Approach. The Project approach can help children develop cognitive skills, especially problem-solving skills, as it exposes them to the everyday problems that demand solutions. Also through the project approach a child-has the opportunity to work a group to develop social skills and especially skills in collaborating with others. Gonzales and Mena (2008) stated that the project approach is "An in-depth teaching learning process emerges from an idea That-thought up by either a child or an adult and is carried out over days or weeks. Unlike free play, project work emphasizes the product as well as process. Documentation of the process (During and open-completion) is an Important element of the project approach. In line with this, Katz and Chard (Follari, 2008) revealed that the project approach is a key feature of project work is that it is an investigation-a piece of research that involves children seeking answers to questions they have formulated. In the project approach, teacher and children work together to generate a list of question and map out how concepts relate to one another within the scope of the project topic or theme.

The project approach is a form of learning which exposes children to the everyday problems that exist and must be solved individually or in groups. This method is a form of child-centered approach, because children have the opportunity to learn to find a way out of problems they face. The abilities can be developed through the use of this method include: the ability to socialize, work and asking for help. In addition, the project approach objective is to develop the moral aspect and discipline in children. In project work, the four learning goals must be explored individually (Katz and Chard cited in Follari, 2008) are knowledge, skills, dispositions and feelings. At the core of the project approach is the premise that children's learning is optimized intellectually. They are engaged in the learning environment (Katz and Chard cited in Follari, 2008)

Project approach gives freedom to the child to perform activities in accordance with their respective interests. They will conduct the search process, collect data, organize and even present the data. Consequences that would arise as the child will have a high involvement with his work and highly motivated to finish the job. Increased freedom possessed child will affect the role of teacher. If the traditional teaching of teachers to act as a determinant of the direction on the method of learning the teacher projects more as a facilitator who will provide facilities to children to learn, while kids have the freedom to conduct activities in accordance with their wishes.

Stages that can be achieved in the implementation of the project approach are as follows:

a. Planning and questioning

b. Investigating and Researching

c. Concluding and culminating (Follari, 2008)

Basically, project approach offered an opportunity for children to learn through various learning experiences that are available.

\section{CONCLUSIONS}

Humans have a very close relationship with its environment because humans are part of the environment itself. Environmental education given at an early age is expected to develop into a positive attitude towards the environment and will carry over into adulthood. Thus, environmental education should be an essential part of early childhood curriculum. However, the application needs to use strategies appropriate to their developmental stage. Early childhood should be provided with learning experiences that is direct and challenging so it will be fun and meaningful for young children. The project approach as one strategy that is loaded with direct experience and bring children to learning by doing can be an alternative choice of strategy for teachers in introducing the environment and directly interact with the environment. 


\section{REFERENCES}

Chen, Judith., Cheng, Hsuan (2008). Children, Teachers and Nature: An Analysis of an Environmental Education Program (Disertasi). University of Florida.

Council, V. E. E. (1992). Learning to care for our environmental: Victoria's Environmental Education Strategy. Melbourne: Victorian Educational Environmental Council

Elliot, S., Young, Tracy. (2005). Environmental Education Connecting With Nature. Croydon, Victoria: Tertiary Press.

Follari, L. M. (2007). Foundation and Best Practices in Early Childhood Education: History, Theories and Approaches to Learning. New Jersey: Pearson Merril Prentice Hall.

Gonzales, J., Mena. (2008). Foundation of Early Childhood Education: Teaching Children in a Diverse Society. New York: Mc. Graw Hill.

Hildebrand, V. (1981). Introduction to Early Childhood Education (3rd ed.). New York: Mcmillan Publishing Co.

Junge, Sharon K., Sue Manglallan, and Juliana Raskauskas. "Building life skills through afterschool participation in experiential and cooperative learning." Child Study Journal 33.3 (2003): 165+. Expanded Academic ASAP. Web. 3 Sept. 2010.

Kinsella, Rachel (2008) Everyday learning about. Being green. Early Childhood Australia Inc.

Katz, L. G. (2010). A Developmental Approach to The Curriculum in the Early Years (2nd edition ed.). London: Routledge Taylor and Francis Group.

Kurikulum Berbasis Kompetensi. (2003) Jakarta: Departemen Pendidikan Nasional

Lang, J. (2007). Little Books of Big Ideas: How to Succeed with Education for Sustainability. Carlton South Victoria: Curriculum Corporation.

Meiboudi, Hossain (2011). Enhancing Children Environtmental Awareness in Kindergarten Massad City Using Mural Painting. ProcediaBehavioral and Social Sciences 28 (2011) 1020-1028. Available on line at www.sciencedirect.com

Preuss, P., Duke, Geoff. Rogers, Judy. (1998). Environment. Melbourne: Cambridge University Press.

Spodek, B. (1978). Teaching in the Early Years. (2nd ed.). New Jersey: Prentice-Hall, Inc.

Sutrisno, Harjono, Hary Soedarto (2005) Pengenalan Lingkungan Alam Sekitar Sebagai
Sumber Belajar Anak Usia Dini. Jakarta: Departemen Pendidikan Nasional. Direktorat Jenderal Pendidikan Tinggi. Direktorat Pembinaan Pendidikan Tenaga Kependidikan dan Ketenagaan Perguruan Tinggi.

William B. Stapp and Dorothy A.Cox. (1979) Environmental Education Activities Manual. Wiiliam B. Stapp and dorothy A. Michigan 48018 